\title{
Controlling the cowpea black aphid (Aphis craccivora Koch) with botanical extracts
}

\author{
Victor Emmanuel de Vasconcelos Gomes ${ }^{1 *}$ \\ Jefferson Auteliano Carvalho Dutra ${ }^{2}$ \\ Mirla Maria Mesquita Almeida ${ }^{1}$ \\ ${ }^{1}$ Universidade Federal do Ceará, Campus do Pici, CEP 60.440-593, Fortaleza - CE, Brasil \\ ${ }^{2}$ Secretaria Municipal de Agricultura, Pesca e Abastecimento, Itinga do Maranhão - MA, Brasil \\ * Autor para correspondência \\ v.e.de.v.gomes@gmail.com
}

Submetido em 03/03/2019

Aceito para publicação em 03/07/2019

\section{Resumo}

Controle do pulgão-preto (Aphis craccivora Koch) com extratos botânicos. Extratos botânicos de plantas brasileiras de caatinga têm um efeito inseticida potencial e acredita-se que extratos de Ziziphus joazeiro, Caesalpinia ferrea e Mimosa caesalpiniifolia exibam atividade inseticida contra Aphis craccivora (pulgãopreto). Este trabalho teve como objetivo avaliar diferentes extratos botânicos dessas plantas no controle de $A$. craccivora em plantas de feijão-caupi. O estudo foi realizado no Departamento de Fitotecnia da Universidade Federal do Ceará, campus Pici, em Fortaleza, Ceará. Os tratamentos foram: água destilada; um inseticida botânico de eficiência comprovada, da Annona squamosa, na concentração de $0,5 \%$; e extratos hidroalcoólicos, por dois tempos de armazenamento e concentrações de 5 e 2,5\%, de diferentes partes das espécies vegetais. O delineamento de cada experimento foi em blocos casualizados, com vinte e seis tratamentos e cinco repetições. Para ambas as concentrações ( $5 \%$ e 2,5\%), o tratamento que apresentou maior eficiência foi o extrato de Annona squamosa. Nas condições do experimento, os extratos botânicos possuem uma substância ativa que controla o pulgão.

Palavras-chave: Bio-inseticidas; Controle alternativo; Sustentabilidade

\section{Abstract}

Botanical extracts from Brazilian caatinga plants have a potential insecticidal effect and it was thought that extracts of Ziziphus joazeiro, Caesalpinia ferrea and Mimosa caesalpiniifolia would exhibit insecticidal activity against Aphis craccivora (cowpea black aphid). This work aimed to evaluate different botanical extracts of these plants at controlling A. craccivora on cowpea plants. The study was conducted at the Plant Science Department of the Federal University of Ceara, Pici campus, in Fortaleza, Ceará. The treatments where made of the following: distilled water; a botanical insecticide of proven efficiency, from Annona squamosa, at a concentration of $0.5 \%$; and hydroalcoholic extracts, for two storage times and concentrations of 5 and $2.5 \%$, of different parts of the plant species. The design of each experiment was in randomized blocks with twenty-six treatments and five repetitions. For both concentrations (5\% and 2.5\%), the treatment that showed the highest efficiency was the Annona squamosa extract. Under the conditions of the experiment, the botanical extracts have an active substance that controls the aphid.

Key words: Alternative control; Biopesticides; Sustainability 


\section{Introduction}

The insecticidal activity of Brazilian native plants, such as juazeiro (Ziziphus joazeiro), jucá (Cesalpinea ferrea) and sabiá (Mimosa caesalpineifolia), has not been thoroughly investigated, and the efficiency of extracts of these plants at controlling Aphis craccivora Koch, including the impacts of storage, was unknown. A previous study mentions the potential insecticidal activity of $Z$. joazeiro, which is related to the allelopathic activity of the saponins present in the plant (SOUZA, 2014). Data obtained about the efficiency of extracts of C. ferrea suggest that this plant contains primary and secondary compounds with insecticidal action against Nasutitermes corniger, since the extracts caused 100\% mortality of populations of this arthropod (XIMENES; CORREIA, 2009). Mimosa caesalpiniifolia is reported to contain tannins that exhibit insecticidal activity against Bemisia tabacii (CAVALCANTE et al., 2006).

Due to the presence of the biological compounds mentioned above, it was assumed that the botanical extracts of these species might exhibit insecticidal activity against the cowpea black aphid and that the efficiency of control might vary for different dosages and different storage times.

The aim of this study was to evaluate the action of different botanical insecticides made from plant species from the Brazilian caatinga, including different concentrations and different storage times, at controlling A. craccivora on cowpea plants.

\section{Material and Methods}

The work was conducted at the Plant Science Department of the Federal University of Ceará (UFC), Pici campus, in Fortaleza, Ceará.

\section{Plant extracts}

Plants were collected in 2008 and 2012; those collected in 2008 were stored for four years at room temperature before being ground into powder.

The plants were collected at the central campus of UFC, Fortaleza, CE, or acquired in a local market.
The samples were oven dried $\left(72 \mathrm{~h} / 45^{\circ} \mathrm{C}\right)$ and then ground in a mill to obtain the powder.

\section{$5 \%$ extracts $(w / v)$}

To prepare each extraction, crushed plant parts $(5 \mathrm{~g})$ were immersed in $50 \mathrm{~mL}$ of hydrated ethyl alcohol (92.8 $8^{\circ}$ INPM) for $24 \mathrm{~h}$ in a dark environment. After leaving it to rest until decanting, the material was filtered and diluted in an equivalent amount of water to obtain hydroalcoholic solutions at a $5 \%(\mathrm{w} / \mathrm{v})$ concentration. The preparations followed the methodology described by Gonçalves and Bleicher (2006).

\section{$2.5 \%$ extracts (w/v)}

The species that were the most efficient at the concentration of $5 \%$ were applied at a concentration of $2.5 \%(\mathrm{w} / \mathrm{v})$. To obtain the extracts, the same methodology described above was used.

\section{Treatments}

The treatments consisted of distilled water (absolute control), a botanical insecticide of proven efficiency from sugar apple (Annona squamosa) (positive control) at a dosage of $0.5 \%(\mathrm{w} / \mathrm{v})$, and the hydroalcoholic extracts $(5 \%$ and $2.5 \%)$.

\section{Bioassays}

\section{Plant model and aphid infestations}

Two cowpea seeds were sown per plastic cup (300 mL) using a substrate made of sandy soil, vermicompost and vermiculite (at a 6:3:1 proportion). Thinning was performed six days after sowing (DAS), leaving one plant per cup.

Adult insects were reared under ambient conditions on cowpea plants, according to the methodology recommended by Oliveira et al. (2010). In order to evaluate the effect of the hydroalcoholic extracts on the nymphs of $A$. craccivora on Vigna unguiculata (L.) Walp, cowpea plants were manually infested 11 days after planting with five adult females of $A$. craccivora, which allowed the known age of the nymphs to be 
obtained. Females were selected by their bright dark color, round shape and fairly visible cornicle.

The plants were separated into blocks, according to the density of nymphs on the plants, for the application of the treatments. The treatments were applied, including the positive and absolute controls, with a gravity spray gun (ARPREX ${ }^{\circledR}$, model-5) attached to an air compressor.

\section{Experimental design}

The design used in each experiment was randomized blocks with five replicates.

For the first experiment (5\% extract), there were eight treatments and five replicates (i.e., forty plants).

For the second experiment $(2.5 \%$ extract $)$, there were six treatments and five replicates (i.e., thirty plants).

\section{Statistical analysis}

The data obtained from the evaluation were converted with the equation $\sqrt{ }(x+0.5)$. The treatments were compared with an analysis of variance, with averages submitted to Tukey's test at 5\% probability.

The efficiency of the extracts was measured by the number of live nymphs after the application of the extracts and the rate of mortality of the nymphs.
Abbott's formula (ABBOTT, 1925) was used to calculate the relative mortality efficiency.

\section{Results and Discussion}

The positive control ( $A$. squamosa) had an efficiency of $98.8 \%$ and 1.2 live nymphs for the first experiment (Table 1). Parra-Henao et al. (2007) found that extracts from the same species resulted in $25 \%$ inhibition of hatching of Rhodnius prolixus (Hemiptera: Reduviidae).

Of the extracts at the $5 \%$ concentration, the most efficient treatment in terms of nymph control compared to the absolute control (distilled water) was from the leaves of $C$. ferrea that were not stored, which had an efficiency of $51.71 \%$, representing a total of 48 live nymphs.

Higher control efficiency was observed for treatments using leaves that were not stored, with variations up to $25.55 \%$ in the efficiency for the $M$. caesalpiniifolia (stored vs. not stored) extract and $15.09 \%$ for the Z. joazeiro (stored $v s$. not stored) extract. For $C$. ferrea, the difference between the extracts was not statistically significant according to the Scott-Knott test at a 5\% probability level; however, this difference was about $16 \%$.

TABLE 1: First experiment. Concentration (\%), mean number of live nymphs (n) and efficiency of the extracts (\%) on Aphis craccivora Koch. Fortaleza, CE.

\begin{tabular}{lccc}
\hline \multicolumn{1}{c}{ Treatments } & $\begin{array}{c}\text { Concentration } \\
(\mathbf{\%})\end{array}$ & $\begin{array}{c}\text { Live nymphs }^{\mathbf{2}} \\
(\mathbf{\%})\end{array}$ & $\begin{array}{c}\text { Efficiency }^{\mathbf{3}} \\
(\mathbf{\%})\end{array}$ \\
\hline Absolute control (Distilled water) & & $99.4 \mathrm{~d}$ & 0.06 \\
Ziziphus joazeiro - Leaf extract 2008 & 5 & $87.8 \mathrm{~d}$ & 11.67 \\
Ziziphus joazeiro - Leaf extract 2012 & 5 & $60.8 \mathrm{c}$ & 26.76 \\
Caesalpinia ferrea - Leaf extract 2008 & 5 & $64.6 \mathrm{c}$ & 35.01 \\
Caesalpinia ferrea - Leaf extract 2012 & 5 & $48 \mathrm{~b}$ & 51.71 \\
Mimosa caesalpiniifolia - Leaf extract 2008 & 5 & $81 \mathrm{~d}$ & 18.51 \\
Mimosa caesalpiniifolia - Leaf extract 2012 & 5 & $55.6 \mathrm{~b}$ & 44.06 \\
Positive control (Annona squamosa - Seed extract) & 0.5 & $1.2 \mathrm{a}$ & 98.79 \\
\hline CV & & $8.53 \%$ & \\
\hline
\end{tabular}

${ }^{1}$ Means followed by the same letter in the column do not differ statistically from one another by the Scott-Knott test at the $5 \%$ probability level. ${ }^{2}$ For the analysis, the data were transformed by the formula $\sqrt{(\mathrm{x}+0.5)} \cdot{ }^{3}$ Efficiency calculated according to Abbott (1925). 
This shows that the leaves of $Z$. joazeiro and $M$. caesalpiniifolia should not be stored for long periods of time, since the effectiveness of the botanical extracts might be reduced, which is probably related to the volatility of the compounds found in these species.

It was observed that the extracts had low efficiency at controlling A. craccivora and only the extract of $C$. ferrea had an efficiency above $50 \%$. It was thought that the control efficiency would increase as the concentration of the extract increased, as found by Souza (2014), who mentions that the control efficiency of Dactylopius opuntiae using Z . joazeiro extracts was higher for a 20 g. $\mathrm{mL}^{-1}$ concentration compared to a 10 g. $\mathrm{mL}^{-1}$ concentration.

For the second experiment with the 2.5\% concentration of the plant extracts, the positive control (A. squamosa) was also the most efficient (99.8\%) (Table 2). On the other hand, the treatments using the leaves that were stored and not stored did not differ statistically according to the Scott-Knott test at the 5\% probability level. This shows that for the $2.5 \%$ dosage, storing or not storing the leaves does not affect the control efficiency of the botanical extracts.

A dosage of $2.5 \%$ should not be recommended to control $A$. craccivora, since every treatment had an efficiency less than $50 \%$.

Under the experimental conditions, the botanical extracts presented active substances that controlled the aphid, which was observed by comparing the effectiveness of the extracts and the effectiveness of the absolute control; however, the efficiency of the pesticides was low. Storing the leaves of M. caesalpiniaefolia and $Z$. joazeiro decreased the efficiency of the extract for the $5 \%$ concentration but did not decrease the efficiency of the extract of C. ferrea.

The efficiency of the extracts was lower for the 2.5\% concentration. Storing the leaves of M. caesalpiniaefolia and $C$. ferrea did not reduce the efficiency of the $2.5 \%$ concentration.

TABLE 2: Second experiment. Concentration, mean number of live nymphs and efficiency of the extracts on Aphis craccivora Koch. Fortaleza, CE.

\begin{tabular}{lccc}
\hline Treatments & $\begin{array}{c}\text { Concentration } \\
(\mathbf{\%})\end{array}$ & $\begin{array}{c}\text { Live }^{\text {nymphs }} \mathbf{2}^{\mathbf{2}} \\
\mathbf{( \% )}\end{array}$ & $\begin{array}{c}\text { Efficiency }^{\mathbf{3}} \\
\mathbf{( \% )}\end{array}$ \\
\hline Absolute control (Distilled water) & & $98.2 \mathrm{c}$ & 0.00 \\
Caesalpinia ferrea - Leaf extract 2008 & 2.5 & $75.8 \mathrm{~b}$ & 22.81 \\
Caesalpinia ferrea - Leaf extract 2012 & 2.5 & $67.4 \mathrm{~b}$ & 31.36 \\
Mimosa caesalpiniaefolia - Leaf extract 2008 & 2.5 & $78.2 \mathrm{~b}$ & 20.37 \\
Mimosa caesalpiniaefolia - Leaf extract 2012 & 2.5 & $73.2 \mathrm{~b}$ & 25.46 \\
Positive control (Annona squamosa - Seed extract) & 0.5 & $0.2 \mathrm{a}$ & 99.80 \\
\hline CV & \multicolumn{3}{c}{}
\end{tabular}

${ }^{1}$ Means followed by the same letter in the column do not differ statistically from one another by the Scott-Knott test at the $5 \%$ probability level. ${ }^{2}$ For the analysis, the data were transformed by the formula $\sqrt{(\mathrm{x}+0.5)} \cdot{ }^{3}$ Efficiency calculated according to Abbott (1925). 


\section{References}

ABBOTT, W. S. A method of computing the effectiveness of an insecticide. Journal of Economic Entomology, Riverside, v. 18, n. 1, p. $265-267,1925$.

CAVALCANTE, G. M.; MOREIRA, A. F. C.; VASCONCELOS, S. D. Potencialidade inseticida de extratos aquosos de essências florestais sobre mosca-branca. Pesquisa Agropecuária Brasileira, Brasília, v. 41, n. 1, p. 9-14, 2006.

GONÇALVES, M. E. C.; BLEICHER, E. Uso de extratos aquosos de nim e azadiractina via sistema radicular para o controle de moscabranca em meloeiro. Revista Ciência Agronômica, Fortaleza, v. 37, n. 2, p. 182-187, 2006.

OLIVEIRA, J. E. M.; BORTOLI, S. A.; SANTOS, R. F.; MOREIRA, A. N. Desenvolvimento de metodologia de criação e multiplicação de Aphis gossypii: avanços e sucessos. Comunicata Scientiae, Bom Jesus, v. 1, p. 65-68, 2010.
PARRA-HENAO, G.; PAJÓN, C. M. G.; TORRES, J. M. C. Actividad insecticida de extractos vegetales sobre Rhodnius prolixus y Rhodnius pallescens (Hemiptera: Reduviidae). Boletín de Malariología y Salud Ambiental, Maracay, v. 47, n. 1, p. 125 137, 2007.

SOUZA, J. I. R. Potencial inseticida do extrato vegetal de Ziziphus joazeiro sobre Dactylopius opuntiae em palma forrageira. In: CONGRESSO BRASILEIRO DE QUÍMICA, 54, 2014, Natal. Anais... Natal: SBQ, 2014. Versão eletrônica.

XIMENES, C. A. Caracterização e avaliação de atividades biológicas da lectina da Vagem de Caesalpinia ferrea (CfePL). 2009. 136 p. Tese (Doutorado em Ciências Biológicas) Universidade Federal de Pernambuco, Recife. 2009. 